\title{
How Big Data Affects In The Industrial Era 4.0 To The Implementation Of Tax Planning In Indonesia
}

\author{
Mangerbang Simanullang (BC201120013), Michael Alexander Nata (BC201120016) \\ Business Administration Focus on Tax Management, Institut STIAMI, Jakarta, Indonesia
}

DOI: 10.29322/IJSRP.11.07.2021.p11530

http://dx.doi.org/10.29322/IJSRP.11.07.2021.p11530

\begin{abstract}
Today's world has experienced developments mainly due to technological advances. In industry 4.0, various technological advances will be increasingly felt, especially in terms of digital technology. The development of digital technology allows data and information to be processed more quickly and well-integrated into an extensive collection known as big data. Therefore, the concept of big data is becoming more and more developed, especially in industry 4.0. The benefits of big data can also be felt in various public policymaking, one of which is Taxation. Currently, Big data has been widely used in Indonesian Taxation. Big data makes it easier for tax authorities in Indonesia to carry out supervisory activities, extensification to provide services to taxpayers to achieve the main goal, namely optimal tax revenue. Big data and technology in industry 4.0 also influence tax planning. Tax planning is part of tax management which is very dependent on the availability of data and information. The availability of big data, especially in industry 4.0 , will make data and information the basis for making tax planning easier to obtain. This condition, in the end, brought significant changes to the methods used and the makers of the tax planning itself.
\end{abstract}

Index Terms - Industry 4.0, Technological Advancement, Big Data, Tax Planning

\section{INTRODUCTION}

The world today has experienced very rapid development in various fields. One of these developments is marked by the increasingly advanced technology available. Technology has played a significant role in various changes. Advanced technology then makes changes to various methods and ways of working that were previously done manually. The role of increasingly advanced and developing technology is what makes progress in various fields, including industry. The condition where technology increasingly plays an important role and produces significant changes in various sectors of life then gave rise to the term industry 4.0 as a new thing that is increasingly being recognized. Industry 4.0 is a new chapter of the development of science and technology. This phase can be the fourth revolution in the industrial sector since the first industrial revolution. The first industrial revolution was the time when the steam engine was first invented. These discoveries have changed the world and become the basis for future developments. The world today has led to industry 4.0, so that all countries must adapt, including Indonesia. This momentum, if properly utilized, will have various positive impacts, such as the creation of jobs due to an increase in productivity [1].

Industry 4.0, which is supported by various digital technologies, has enabled various data and information processing to be easier and faster. The condition in which the existing information data can be processed in such a way then later gives rise to Big Data. This term refers to conditions where there is such a large amount of data in various forms. The data can assist in analyzing to make various important decisions and other desired goals. Big data in industry 4.0 will be digital data generated from various uses of existing technology. The existence of big data here can be said due to the existence of Industry 4.0, which has been running. Many advantages can be obtained from the use of big data in various fields, including public policymaking. Big data and public policy analysis are relevant and essential to discuss because of the rapid development of science and technology. Industry 4.0 will allow the development of information technology to have implications for big and fast data production. This, of course, will significantly affect the collection and analysis of data carried out by a policy analyst in making a public policy. Policy analysts in the digital Era must understand that the making of a public policy will be closely tied to big data, which is one of the results of changes in the policy environment in the digital Era.

One of the most important public policies in Indonesia is related to Taxation. Taxes have an increasingly important role in the Indonesian economy from year to year. One of these increasingly important roles can be seen in its composition in the APBN, one of the largest sources of income. The importance of the role of the taxation sector makes the tax revenue target always increases from year to year. However, this revenue target in the last five years (2016 to 2020) has never been achieved. This condition shows that there needs to be maximum efforts so that tax revenues can increase. One of these efforts is through tax extensification activities. Extensification activities are believed to be able to run optimally when the technical aspects can be used optimally. The use of technology, especially in industry 4.0, will assist in carrying out various essential analyses such as enriching taxpayers' profiles, looking at relations between taxpayers, and identifying the risk of non-compliance with each taxpayer. The taxpayer's profile can be enriched with information about the behavior and life habits of the taxpayer. Thus, the existence of a taxpayer profile can be empowered to reveal hidden assets and income. When these various analyses can be generated from the use of existing technology, the Directorate General of Taxes produces big data that can be used to optimally pursue tax revenues. About industry 4.0, the Directorate General of Taxes has also tried to adjust to welcoming this phase. Many changes have been made on the service and data processing side. The development of technology has made various services, and data processing lead to digitization. Efforts 
made by the Directorate General of Taxes need to be made to adapt to the conditions of the business sector, which is also increased, leading to industry 4.0. All this is done so that the tax collection process can still run optimally [2].

Industry 4.0 and Big Data make changes to the public policy environment in the field of Taxation and tax planning practices or tax planning by taxpayers. Tax planning is a practice related to doing business engineering and transactions to minimize tax debt but not violate existing provisions. Tax planning can be positive or negative, depending on how it is carried out. In a positive sense, tax planning can be in the form of fulfilling obligations in a complete, correct, and timely manner to avoid wasting resources [3]. The formation of a tax planning will depend on the availability of data and information. The more complete the data and information available, the more specific and better tax planning will be. The data and information in question will be available more optimally in big data in the industrial Era 4.0 today. Tax planning can take advantage of existing big data to produce a more in-depth analysis of a specific condition. This trend also shows that industry 4.0 and big data will eventually create innovations and developments in tax planning.

Big data and tax planning have a relationship with each other, which is very interesting to study in-depth. Many previous studies have also discussed this. However, none of the existing studies link it with industry 4.0 and the challenges faced in implementing big data in the tax planning process. Various existing studies pay more attention to the effect of big data on tax planning in general. The results of previous studies explain that big data will have a positive impact on the formation of tax planning. In theory, this is the case, but it should also be remembered that the conditions of each country are not the same, and this is also a determining factor. Some countries are still lagging in terms of technology compared to developed countries in America and Europe. This condition will make existing big data not necessarily able to have a positive impact on tax planning, considering that big data processing requires supporting technology and users who have expertise. This is interesting to study further to understand how big data influences the industrial era 4.0 on the implementation of tax planning.

\section{THEORY BASIS}

Big data can be interpreted simply as a large and fast volume of data. In policymaking, big data can also be defined as a series of activities to collect and analyze big data to produce a policy. Big data is at least characterized by five things, namely [4]:

\section{a. Velocity - speed}

In today's Era, someone will quickly be able to produce data quickly in the form of text, images, videos, or other forms. The sophistication of cellphones, laptops, PCs, and cameras has helped many people to create data quickly.

\section{b. Volume - quantity}

This shows that super-large data indicate the Big Data Era. When everyone can produce data quickly, it is conceivable that the accumulation of data produced today is an extensive data set.

\section{c. Variety - diversity}

This shows that in the Big Data Era, where everyone can produce data independently, it is inevitable that the diversity of data is also very available in this Era. A person can choose what kind of data to produce, whom he produces, and what media to use. It is a realm that has a comprehensive and accessible area.

\section{d. Veracity - trust}

This shows that in the Big Data Era, which gives everyone the freedom to produce and process data, it is essential to sort out diverse data, retrieve credible and valid data, and ignore fake or hoax data. The Era of big data requires someone to be a person who can be trusted by only taking trusted data and producing reliable data.

\section{e. Value - meaning}

This indicates that when data is produced quickly and at large, data analysts are needed to process data into useful and reliable information. This interpretation must, of course, be carried out objectively and must have the vision to provide benefits to many people.

The application of big data can also be carried out in the public sector so that it will systematically define the following administrative functions [4]:

\section{a. Public surveillance}

is identify deviations (e.g., legal disobedience) and take responsive action; public regulations, namely regulating social behavior and establishing social relations through permits, prohibitions, or orders; and public service delivery, i.e., providing certain services or products (including infrastructure such as roads).

\section{b. Artificial intelligence analysis using big data in the crisis-era}

Artificial intelligence can be developed to identify the characteristics of companies and the external environment that positively or negatively affect the resilience of companies to crises such as in the economic field. 


\section{c. Data analysis in the Era of big data offers new efficiencies.}

The challenge for researchers and policy analysts is to design new data-driven models that can be used to understand the complexities of today's and future challenges. This new design calls for collaboration between research and the design of new policies. The absolute thing right now is education that can eliminate confusion in terms of technology and data analysis.

Public organizations must prepare several things in using big data for policy analysis, including the following [4]:

\section{Prepare IT governance (IT Governance)}

This refers to efforts to encourage sub-systems to be integrated into one integrated information system to collect data comprehensively. A comprehensive data set will support reliable policymaking.

\section{Prepare commitments in encouraging the use of big data}

This section refers to efforts to encourage internal commitment to believe in new processes and systems in policymaking and to assure external parties that big data-based policymaking will be carried out responsibly.

\section{Prepare to obey the law.}

Policy analysts must prepare themselves to comply with the law in the use of big data in the formulation of public policies. Policy analysts do not just get stuck looking for extensive, valid, and credible data, then sacrifice the values of honesty and respect for copyright.

\section{Prepare development plans and strategies.}

Public organizations here must prepare designs and development strategies to collect data, ensure data quality, and establish cooperation with partners in terms of data sharing. The digital Era offers openness, and this Era is an excellent time to collaborate with multiple partners to collect reliable data to design policies.

\section{Encouraging education for the use of big data}

Public organizations should encourage professional education in data science. The Government is responsible for providing experts in IT, business, statistics, mathematics, and policy to collaborate in collecting, processing, developing alternatives, recommending, and evaluating public policies. All of that must be done seriously so that the people in charge of public policy analysis are friendly with big data. As a result, the quality of policies will be more scientific and responsible.

Tax planning or also known as tax planning, is an effort made to minimize taxes. These efforts are carried out by engineering taxpayers' businesses and transactions to minimize tax debts but still do not violate the applicable legal provisions. Tax planning is the first step in tax management. At this stage, the collection and research of tax regulations will be carried out to choose the type of tax-saving measures to be carried out. For a tax planning to run well, there are the following stages in its formation [3]:

1. Analysis of the existing database

2. Design one or more possible tax plans

3. Evaluating a tax plan

4. Debugging the tax plan

5. Updating the tax plan

In addition, it should also be understood that there are tools that will support a tax plan to run well, namely as follows [5]:

1. Understanding of tax provisions

2. Good administration and documentation

3. Maintain good relations and communication with external parties (Fiscus) and internal parties (Head of divisions, top management, and tax consultants)

4. Implementation of tax planning

\section{RESEARCH METHODOLOGY}

This study uses a qualitative method that aims to obtain a complete and thorough understanding of the actual problems that occur in the community. In solving existing problems, this research uses a case study approach. The case study focuses on the implications of big data in the industrial era 4.0 on the implementation of tax planning in Indonesia. The implications will be seen in how big data has a positive or negative impact on implementing tax planning. The data used in this study uses primary and secondary legal material data. Primary legal material data is in the form of data that is authoritative or has authority. This data is obtained in legislation, official records, minutes of making legislation, and judges' decisions. The secondary legal material data is in publications on the law, which are not official documents. Publications on law include books, legal dictionaries, legal journals, and commentary on court decisions. [6] 


\section{DISCUSSION}

\subsection{Big data in the context of Taxation}

Big data and industry 4.0 are two things that cannot be separated. Big data is widely understood as a result of industry 4.0 itself. The existence of industry 4.0 will be marked by progress, especially in the field of technology. Many advanced technologies, especially digital ones, will experience rapid development. This growing digital technology will make various data that used to be in the physical or manual form will be transferred to digital form. This transfer process is carried out because advanced digital technology will facilitate the collecting, manufacturing, and processing of existing data and information. As a result, data and information will be collected and processed more quickly to emerge into an extensive collection termed big data. The primary function of big data is to assist in making important decisions. For analysts or decision-makers, the existence of big data will seem to be a data bank or database for consideration before a decision is made. The development of big data is believed to continue to increase along with the world that has entered the industrial phase 4.0 with various advances in digital technology.

The utilization of big data can be used in various fields for decision making, including, in this case, in the field of Taxation. This is important for Indonesia, considering that the taxation sector is currently trying to improve reforms. This tax reform effort is needed considering that there are still many problems in the field of Taxation in Indonesia. Moreover, as we all know, currently, the world of Taxation in Indonesia can be said to be experiencing problems. The problem is not related to mathematical and economic problems. Tax problems in Indonesia are thicker with sociological and psychological aspects, including legal issues and public agreements. This also shows that human quality in living together is the root of the existing problems [7].

Some solutions that can be done to overcome the problems of the tax system in Indonesia include welfare and legal example, improvement of tax information technology, cooperation with Rural Banks, Facilitating access to banking. Especially about the improvement of tax information technology, this requires technological advances and their application. Apart from that, it is also necessary to make efforts to improve tax information systems, data processing information systems, and tax object information management systems. In addition, other efforts that can be made to improve technology are the application of information networks within tax institutions both at the central and regional levels. This improvement is carried out to improve the elements of good governance so that transparency, accountability, and public participation in various tax activities are built [8]. The improvement in information technology can also be said as an effort in terms of modernizing tax administration. The existence of computer-based technology improvements can be one element for tax reform. This is because the improvement in tax administration will minimize the opportunity for unscrupulous individuals to take commendable actions, which is a problem related to the low compliance of taxpayers [9].

In the world of Taxation, Big Data will integrate various financial data in addition to data related to banking and finance. In addition to this banking data, the Government can use data held by telecommunications companies, the internet, and online shops to obtain data on candidates/taxpayers. The data is in the form of IP address data, HP user location data, transaction data, and other data. Based on these data, the Government can identify the economic patterns of the candidate/taxpayer, such as:

a. using data from telecommunications companies to find out the money used to spend credit, what percentage of the funds were spent on buying credit, and how much it compares to the general public.

b. They are using telecommunications data to find out the position of taxpayers through mobile phones throughout the year. For example, knowing where taxpayers carry out their activities, whether to malls, commercial places, more at home, or traveling to various places.

c. They are using data from telecommunications companies and internet hosting companies to find out the website's address, whether the taxpayer conducts electronic transactions or other economic matters.

d. Using data from online stores to find out who visited and made purchases at the online store and how much money was spent. From these data, the Government will undoubtedly get strategic information about anyone who has the potential to become a taxpayer or related to tax intensification. Because it may be that so far, many have not caught the Government's radar because prospective taxpayers run businesses informally but have a reasonably significant turnover. Alternatively, maybe, the tax report in the SPT is low but often travels at home and abroad. The Government can also examine taxpayers who are believed to have high tax potential but report taxes in low amounts from this data.

The explanation above points to how big data can help extensification efforts in the taxation sector. Of course, the tax extensification/intensification effort cannot be made alone by the Government, especially the Directorate General of Taxes (DGT). It needs cooperation between DGT and several parties such as telecommunications companies, internet hosting companies, and online shop owners. Synergy with these parties is needed to summarize and obtain data on taxpayers/prospective taxpayers' economic activities while profiling taxpayers themselves in a relatively more accessible way than conducting a census. However, this effort needs a more in-depth study because there are data and sensitive matters mainly related to data confidentiality and the convenience of residents. In addition, this effort still needs to be studied more deeply, especially regarding the costs and benefits received by the Government and the resulting impact.

Another form of using big data in Taxation is related to supervision activities for registered taxpayers. One of the supervisory policies that can be applied here is the classification based on the level of taxpayer risk. This method is done by creating a compliance risk management (CRM) system. CRM is an instrument to map taxpayers based on their level of risk. Through 
extensive data analysis, DGT can create a unique algorithm to rank the taxpayers' risk. Follow-up actions are forwarded to taxpayers depending on the level of risk, namely being examined, supervised, or adequately educated. The CRM system will be the driver of the taxpayer's compliance strategy. The authority can establish a particular unit with human resources to manage it. In addition, CRM needs to be developed according to specific groups of taxpayers or sectors supported by predictive data analysis, trends, and taxpayer behavior. Authorities also need to develop self-service analytics and conduct integrated analysis in business intelligence. Digitalization of the tax system and enforcement of regulations is expected to encourage an increase in tax compliance which is correlated with the tax ratio. Of course. In realizing the tax revolution, the Government requires the involvement of many parties in its implementation. Thus, the purpose of developing the tax system can be realized according to the plan.

About using big data, prominent data experts must synergize with various parties, such as financial data analysts, to produce information in the form of data that tax practitioners will interpret. The concept of synergy is a strategic effort to predict an accurate model of tax fraud. In addition, the concept of continuous improvement needs to be focused on improving the current system. This, in turn, can create an appropriate, effective and efficient tax system for Indonesia. The use of a CRM mechanism, which is supported by the use of big data, will enable the Directorate General of Taxes to be able to detect fraud automatically and create a system-wide 'forced to be honest' condition, not only related to tax fraud but also all fraud that occurs, including corruption.

About Big Data, this has become a serious concern from the Government with the issuance of Presidential Decree No. 72 of 2004 to accommodate transparency by building big data in the state revenue and expenditure budget. Big Data continues and is consolidated in Government Regulation No. 7 of 2005 concerning the National Medium-Term Development Plan for 2004-2009 and the Decree of the Minister of Finance No. 84/KMK.01/2006 concerning the Strategic Plan of the Ministry of Finance for 20052009. This policy aims to increase tax revenue through big data. Big data automatically integrates financial and non-financial data outside the tax apparatus into a nationally centralized Tax Data Bank and then performs matching the transaction data with the Taxpayer's SPT.

It is also essential to understand that big data is for e-appeals and broader tax purposes. It starts from collecting various taxpayer data, proactive services without face to face to detecting tax avoidance, tax evasion, and other illegal activities. The challenge of data application in Indonesia is the lack of knowledge about data technology. On the other hand, the ability to manage data is also rarely mastered. Therefore, it is necessary to improve the quality of data management human resources, especially those engaged in the tax sector. An example of using information technology in extracting big data is XBRL (extensible business reporting language), used by the Indonesia Stock Exchange to transmit and exchange information. XBRL can increase efficiency, speed and automate data processing that supports analysis and quality of information. Of course, it will be a challenge whether XBRL can be implemented in the tax sector in the future. Big data and XBRL, whose functions resemble a role in data collection, are beneficial for detecting Taxation and facilitating the audit process. The Government has moved to provide convenience for taxpayers by utilizing technology, but not all taxpayers can adapt quickly to this change.

Moreover, not all people are familiar with the use of technology. In addition to utilizing technology, the Government's challenges include socialization and education on the use of technology. In addition, innovation is also an ongoing challenge for the Government to continue developing and updating the services provided to taxpayers by adjusting the situation and always paying attention to the ease of paying taxes. Technology can influence the way people communicate, connect, innovate, create, and pave the way for opportunities. However, education is something that cannot be replaced. If technology is not used correctly, technology is the only technology that does not positively impact. Technology should produce a fair taxation system and improve the quality of services that make it easier for taxpayers.

Based on the current conditions in Indonesia's taxation world, especially related to the problem of the low tax ratio, at least efforts should be made to resolve it through big data. Big data will assist the Government in obtaining information, especially regarding economic activities carried out by prospective/taxpayers. This information can be used to profile taxpayer data based on location patterns, monthly credit users, online store transactions, frequency patterns, and the intensity of communication through the internet network. Thus, there is a gap for the Government to seek tax extensification through big data. Therefore, various intensification and extensification efforts relevant to the times must continue to be intensified so that the tax revenue target can be achieved and the use of big data technology, which is expected to increase the level of tax compliance.

Moreover, so far, many parties tend not to fulfill their tax obligations. Therefore, another function of the existence of big data, one of which is to conduct fraud analysis, namely the tendency to disobey, can be reduced. The application of extensive data analysis in the context of tax revenue has many potentials, such as enriching the profile of taxpayers, seeing the relationship between taxpayers, and identifying the risk of non-compliance of each taxpayer. In addition, the taxpayer's profile can be enriched with information about the behavior and life habits of the taxpayer. Thus, the existence of a taxpayer profile can be empowered to reveal hidden assets and income.

Furthermore, related to the relationship between taxpayers, the authority can detect groups of interconnected taxpayers, especially in financial matters. Thus, all financial transactions that occur between them can be detected. This can be used to read patterns of fraud or tax evasion. The supervision can be focused on groups of taxpayers with a high risk of non-compliance. In essence, big data with the proper implementation of technology contains excellent potential in combating tax evasion. Not only able to detect tax evasion, but this extensive data system also makes tax data processing faster. Big data makes processing 7,200 times faster than the Relational Database Management System (RDBMS) used by the previous DGT.

It is also essential to understand that reforms and changes related to the tax collection and administration system are essential to prevent adverse impacts on the country's economy in the Era of big data. Tax authorities need to continually synergize and exchange information with other departments within a country. In addition, the Government must also play a role, especially in terms of strengthening the provisions as a legal aspect of a tax collection activity. When there is no support and good synergy between the Government and the existing tax authorities, of course, big data will not be of much use and will create new problems. 
The problem referred to here is related to the possibility of incorrect and inappropriate information, which will result in errors in decision-making [10].

\subsection{Big data pada in industry 4.0 as an essential factor in tax planning}

Big data in industry 4.0 will be easier to obtain. Advances in digital technology allow the processing of data and information to be faster and helpful in various fields. One of the uses of big data is in the field of Taxation. Big data in the context of Taxation will provide benefits for the Government as policymakers and taxpayers themselves. The majority of taxpayers will certainly not be happy with the existence of taxes. Taxes are considered as something that is trying to be avoided because it reduces the rights that should be received. Efforts to avoid taxes can be made illegally or legally. When it is done legally, it is generally closely related to tax planning. Tax planning allows taxpayers to make tax savings but in a legal way or not violate the law. Tax planning is currently receiving increasingly serious attention from many companies. The savings generated by tax planning will significantly assist the company in making efficient use of its resources, mainly if the company is located in a country with high tax rates.

Tax planning is widely misunderstood because often taxpayers cannot clearly distinguish between tax avoidance and tax evasion. The understanding of tax planning is widely understood only as an effort to make lower tax payments. Whereas tax planning, if it can be appropriately used, will also directly impact a business entity's financial management and business development strategies. However, it should also be understood that tax planning also has risks, both caused by internal and external factors. Internal factors are related to the subjectivity of the maker or party who designs the tax planning. The approach adopted by the maker will determine how the form of tax planning is produced. The type of maker who has an aggressive approach will tend to lead to tax evasion.

In contrast, a conservative approach will lead to tax avoidance but does not necessarily provide significant savings. Then for external factors will point more to the current uncertainty. The uncertainty here is related to, for example, changes in government policy in the field of Taxation. The existence of these changes could completely change the tax planning scheme that has been made, and this is very difficult to predict in advance [11].

Tax planning will continuously develop from time to time. This development will be even more rapid when connected to industry 4.0. In industry 4.0, there will be many digital technologies with high quality for processing existing data and information. Many of these data and information will be converted into digital form and processed with existing technology to form a large amount of data. This extensive and integrated collection of data is what is termed Big Data. The existence of big data is what directly affects the pattern and development of tax planning. It can be said that industry 4.0 has changed the pattern of tax planning that used to be traditional to become more modern. Many companies from various fields are currently also trying to adjust to the transition from tax planning.

Big data and tax planning are two interrelated things. Patterns and methods in the formation of tax planning will be better with big data, especially in industry 4.0. This is because the making of tax planning is very dependent on data and information. Big data has advantages compared to conventionally obtained data and information. These advantages include the speed in the acquisition, which will be a lot of digital data. The more advanced the technology, the faster the acquisition of big data will be. In addition, the large volume and large variety of data are also other advantages of big data. Significant data users, in this case, will find it easier to analyze the data needed for later use in making decisions. If it is associated with tax planning, it is necessary to re-understand how the stages in making it are. As it is known that the stages of making a tax plan will start from analyzing the existing data set, designing the tax planning model, evaluating and updating the existing tax planning model. Big data and technology in industrial Era 4.0 will affect every stage in doing tax planning. Big data will form the basis for making the analysis broader and more profound at the data analysis stage because big data will become a data and information bank.

Furthermore, when designing the tax planning model that will be applied, technology and big data in industry 4.0 will provide various possibilities and models by utilizing the existing system. Evaluation and analysis of weaknesses in tax planning are also getting faster, easier, and better with technology and big data. Technology and big data will provide a more comprehensive picture of the implementation of tax planning so that various existing problems can be observed and resolved more quickly with the help of existing technology.

The more and more complete the data and information available, the tax planning made will be supported by in-depth analysis. In the industrial Era 4.0, big data will play an essential role because it becomes the basis for making a tax plan. However, what is no less important is the technology used to process and produce the big data. As previously stated, digital technology will dominate in the industrial Era 4.0. In industry 4.0, big data processing technology will be the foundation of tax planning. This technology will make tax planning better and can be adjusted to the needs. One concrete form of digital technology that will help big data processing and tax planning is artificial intelligence technology.

Artificial intelligence technology will make a change and a new development. This technology can provide support in terms of data collection and processing for decision-making. Data processed from this technology will help make decisions more accurate and effective. Artificial Intelligence, as artificial intelligence that resembles humans, will also analyze various problems in tax planning by making various models and possibilities. The analysis results will produce the most appropriate tax planning pattern and method proposals by eliminating the possibility of existing risks. The use of artificial intelligence and providing complete data results also makes predictive analysis better. This predictive ability is essential in terms of mitigating various risks that may arise from the decisions that have been made. Therefore, if artificial intelligence, big data, and tax planning can be integrated, they will provide maximum efficiency.

Based on the explanation above, it is clear that tax planning, big data, and technology in industry 4.0 will be interrelated. Tax planning will undoubtedly be able to get better and develop with the various components. However, it should also be remembered that technology and big data in industry 4.0 are not only the main thing so that tax planning can run well. This is because many other supporting tools include understanding tax provisions, good administration and documentation, good relations with external 
parties, and implementation. From these tools, it appears that the user factor will also be very decisive so that big data and technology can be of maximum benefit for tax planning. Users of tax planners are required to follow and adapt to various technologies in the industrial Era 4.0. Tax planners are required to be able to use computerized technology, especially in terms of data processing. Therefore, the capabilities of the tax planners must include, among others, tax, finance, legal, and other supporting knowledge.

Big Data capabilities will develop as the Big Data resources section, and the skills and competencies section are integrated and then grow into dynamic capabilities. This shows that big data in an organization is primarily determined by the organization's ability to collect data and develop skills/competencies to process big data. If the two are integrated, the organization's ability to utilize big data will be better. All decision-making bodies should try to get experts in Big Data analysis to help in policymaking. When there are no supporting experts, it will result in significant data not being optimal. Big data and technology are only tools to support, so it depends on the party who uses it. In addition, the mastery of technology from a country is also an essential factor in supporting the use of big data for tax planning purposes. In industry 4.0, technology will undoubtedly be very advanced, and big data can easily be obtained with the help of technology. In such conditions, it depends on how the tax planner can use these various resources. When the tax planners are not able to use it optimally, in the end, it will make digital technology and big data meaningless or, more accurately, just wasted. Therefore, there needs to be consistency and firmness so that tax planners can adapt to the various changes that exist. For this reason, the leading factor in an organization and corporation will also determine the adjustment effort [12].

\section{CONCLUSION}

Based on the discussion that has been presented, several essential things can be understood, namely:

1. Industry 4.0 makes processing Big data easier due to technological developments.

2. Big data in the industrial Era 4.0 will support better tax planning if it can be processed more carefully.

3. Big data processing in the industrial Era 4.0 has challenges, namely experts and supporting facilities and infrastructure.

4. Various limitations, especially in terms of experts and facilities, and infrastructure, will potentially make big data a waste.

\section{REFERENCES}

[1] Alamsyah, R. Analisis Dampak Industri 4.0 Terhadap Sistem Pengawasan Ketenaganukliran Di Indonesia. Jurnal Forum Nuklir, vol 12 No 2, 2018, 47-54.

[2] Krause, D. G. The Way of the Leader. Diterjemahkan oleh PT Gramedia Dengan Judul Kiat Sang Pemimpin. PT Gramedia Pustaka Utama. Jakarta. 2000.

[3] Suandy, E. Perencanaan Pajak - Edisi ke 5. Salemba Empat. Jakarta. 2014

[4] Slamet, R. Indiahono, D. Administrasi Publik New Normal. SIP Publishing. Jawa Tengah. 2020

[5] Pohan, C.A. Manajemen Perpajakan - Strategi perencanaan Pajak dan Bisnis. Edisi Revisi. PT. Gramedia Pustaka Utama. Jakarta. 2013

[6] Marzuki, P.M. Legal Research. The tenth print. Prenamedia Group. Jakarta. 2015.

[7] Mere, K. Panorama Pajak dan Permasalahannya. Cetakan Pertama. Dioma. Malang. 2008

[8] Widodo, W. Moralitas, Budaya, dan Kepatuhan Pajak. Cetakan kesatu. Alfabeta. Bandung. 2010.

[9] Burton, R. Mitra Kajian Perpajakan dalam Konteks Kesejahteraan dan Keadilan. Wacana Media. Jakarta. 2014

[10] Wang, L. Research On Tax Collection and Administration Based On Big Data Analysis. International Conference on Intelligent, Big data, and Smart City. 2020

[11] Shan, J.J. Optimization Strategy of Tax Planning System in the Context of Artificial Intelligence and Big Data. Journal of Physics: Conference Series, 1345 052006, 2019.

[12] Oberer, B. Erkollar, A. Leadership 4.0: Digital Leaders in the Age of Industry 4.0. International Journal Of Organizational Leadership. Sakarya University, Business School. Turkey. 2018 